\title{
Characterization of Proteins Regulated by Androgen and Protein Kinase a Signaling in VCaP Prostate Cancer Cells
}

\author{
Hye-Jin You ${ }^{1,2} \mathbb{D}^{\text {, Byong-Chul You }}{ }^{1,2}{ }^{\oplus}$, Jong-Kwang Kim ${ }^{3}{ }^{-}$, Jae-Min Park ${ }^{2}$, Bo-Seul Song ${ }^{2}(\mathbb{C}$ \\ and Jae-Kyung Myung ${ }^{2, *}$ (i)
}

1 Division of Translational Science, National Cancer Center, 323 Ilsan-ro, Ilsandong-gu, Goyang-si 10408, Korea; hjyou@ncc.re.kr (H.-J.Y.); yoo_akh@ncc.re.kr (B.-C.Y.)

2 Department of Cancer Biomedical Science, National Cancer Center-Graduate School of Cancer Science and Policy, 323 Ilsan-ro, Ilsandong-gu, Goyang-si 10408, Korea; jam9192@naver.com (J.-M.P.); mawsonyya@naver.com (B.-S.S.)

3 Research Core Center, National Cancer Center, 323 Ilsan-ro, Ilsandong-gu, Goyang-si 10408, Korea; jkkim.gensdei@gmail.com

* Correspondence: jmyung.sci@gmail.com; Tel.: +82-31-920-2746

Citation: You, H.-J.; You, B.-C.; Kim, J.-K.; Park, J.-M.; Song, B.-S.; Myung, J.-K. Characterization of Proteins Regulated by Androgen and Protein Kinase a Signaling in VCaP Prostate Cancer Cells. Biomedicines 2021, 9 , 1404. https://doi.org/10.3390/ biomedicines 9101404

Academic Editor: Filippos Koinis

Received: 30 August 2021

Accepted: 2 October 2021

Published: 6 October 2021

Publisher's Note: MDPI stays neutral with regard to jurisdictional claims in published maps and institutional affiliations.

Copyright: () 2021 by the authors. Licensee MDPI, Basel, Switzerland. This article is an open access article distributed under the terms and conditions of the Creative Commons Attribution (CC BY) license (https:// creativecommons.org/licenses/by/ $4.0 /)$.

\begin{abstract}
Androgen signaling via the androgen receptor (AR) is involved in normal prostate development and prostate cancer progression. In addition to androgen binding, a variety of protein kinases, including cyclic AMP-dependent protein kinase A (PKA), can activate the AR. Although hormone deprivation, especially that of androgen, continues to be an important strategy for treating prostate cancer patients, the disease ultimately progresses to castration-resistant prostate cancer (CRPC), despite a continuous hormone-deprived environment. To date, it remains unclear which pathways in this progression are active and targetable. Here, we performed a proteomic analysis of VCaP cells stimulated with androgen or forskolin to identify proteins specific for androgen-induced and androgen-bypassing signaling, respectively. Patterns of differentially expressed proteins were quantified, and eight proteins showing significant changes in expression were identified. Functional information, including a Gene Ontology analysis, revealed that most of these proteins are involved in metabolic processes and are associated with cancer. The mRNA and protein expression of selected proteins was validated, and functional correlations of identified proteins with signaling in VCaP cells were assessed by measuring metabolites related to each enzyme. These analyses offered new clues regarding effector molecules involved in prostate cancer development, insights that are supported by the demonstration of increased expression levels of the eight identified proteins in prostate cancer patients and assessments of the progression-free interval. Taken together, our findings show that aberrant levels of eight proteins reflect molecular changes that are significantly regulated by androgen and/or PKA signaling pathways, suggesting possible molecular mechanisms of CRPC.
\end{abstract}

Keywords: castration resistant prostate cancer; proteome; metabolites; signaling pathway; androgen

\section{Introduction}

Prostate cancer is the most common cancer and the second leading cause of cancer death among men. Between 1973 and 2013, prostate cancer incidence rates increased in all parts of the world [1]. When detected early, 70-80\% of prostate cancer cases can be completely cured through surgery and castration therapy. Hormone (androgen) deprivation is also an important approach for treating prostate cancer patients. However, after 6 to 36 months of androgen-deprivation therapy (ADT), prostate cancer recurs in $20 \%$ of cases and develops into intractable castration-resistant prostate cancer (CRPC) [2,3], implying the involvement of other androgen-independent signaling pathways in CRPC progression.

Studies undertaken to understand the mechanism of CRPC development have indicated the active involvement of the androgen axis in CRPC growth [3-6]. Research reported that intratumoral androgens are synthesized in situ and that their metabolism contributes 
to CRPC [7-13]. Mutations, alternative splicing, and other alterations of the androgen receptor (AR) gene have been proposed to affect signaling within CRPC [14-19], suggesting the involvement of complex signaling pathways.

Testosterone, the main hormone involved in early prostate development, can be converted to dihydrotestosterone (DHT) via 5 alpha-reductase $[20,21]$. DHT is responsible for activating androgen signaling and facilitating continued AR signaling in the progression to CRPC [22]. The AR is a member of the steroid receptor family of transcription factors, which share structurally conserved domains, including a DNA-binding domain (DBD), a ligand-binding domain (LBD), an N-terminal domain (NTD), and a hinge region that contains a nuclear localization sequence.

Androgen-dependent prostate cancer can be treated through targeting androgen synthesis or the AR ligand-binding domain [23,24]. However, CRPC is almost impossible to treat because of the operation of androgen-independent mechanism involving a variety of protein kinases, including cyclic AMP-dependent protein kinase A (PKA) and ligand binding domain-deleted AR variants (AR-Vs) [25].

PKA is activated by the second messenger, cAMP [26-28], that are necessary for the proper biological response of cells to hormones and other extracellular signals [29]. This PKA-signaling pathway can be stimulated by the synthetic compound forskolin (FSK), which acts directly on adenylate cyclase to increase intracellular levels of cAMP, thereby, inducing PKA-dependent AR activation [27,30-32].

The molecular expression profiling of prostate cancer cells has led to the identification of expression patterns that are associated with specific phenotypes and prognosis. Differential expression has been determined in prostate cancer cells stimulated with androgen-induced or PKA-induced AR signaling by treating cells with DHT or FSK, respectively [33-35].

To date, there are no protein expression profiling of androgen- and PKA-induced VCaP cells, which are one of the most representative CRPC models with amphicrine feature [36]. Here, using two-dimensional electrophoresis (2DE), we identified differences in proteomes between androgen (DHT)- and PKA (FSK)-stimulated VCaP prostate cancer cells and control (untreated) VCaP cells. Ultimately, the identified significant differences in proteins induced by DHT and FSK treatment may provide insights into prostate cancer progression and help guide the development of new CRPC treatments.

\section{Materials and Methods}

\subsection{Cell Culture and Treatment}

VCaP cells were obtained from American Type Culture Collection (ATCC, Rockville, MD, USA). Cells were previously authenticated by the NCC Omics Core facility (Perkin Elmer, Waltham, MA, USA) using the short-tandem repeat (STR) polymerase chain reaction (PCR) method. Cells were cultured in Dulbecco's Modified Eagle's medium (DMEM; SigmaAldrich, St. Louis, MO, USA) containing 10\% fetal bovine serum (FBS; Gibco, Carlsbad, CA, USA), $100 \mu \mathrm{g} / \mathrm{mL}$ streptomycin, and $100 \mathrm{U} / \mathrm{mL}$ penicillin (Gibco). Cells were incubated at $37^{\circ} \mathrm{C}$ in a humidified $5 \% \mathrm{CO}_{2}$ environment. $\mathrm{VCaP}$ cells were serum-starved and treated with $10 \mathrm{nM}$ DHT or $1 \mu \mathrm{M}$ FSK for $3 \mathrm{~h}$.

\subsection{Protein Sample Preparation and $2 D E$}

Proteins were extracted from cells using a urea lysis buffer (7 M urea, $2 \mathrm{M}$ thiourea, $65 \mathrm{mM}$ CHAPS, 0.5 M EDTA, $50 \mathrm{mM}$ Tris, $0.01 \%$ BPB, and $65 \mathrm{mM}$ DTT) supplemented with protease inhibitors (Roche), $200 \mathrm{mM}$ PMSF (phenylmethylsulfonyl fluoride), and ampholytes. Cell lysates were desalted and concentrated using Amicon ultra centrifugal filters (Merck Millipore, Darmstadt, Germany), and the resulting protein concentration was measured using a Bradford protein assay kit (Bio-Rad, Hercules, CA, USA) according to the manufacturer's instructions.

Proteins were resolved by 2DE, which separates proteins based on isoelectric point (first dimension) and size (second dimension). For isoelectric focusing (IEF), each pro- 
tein sample was loaded on an IPG strip (pH 3-10 NL; $130 \mathrm{~mm} \times 3 \mathrm{~mm} \times 0.5 \mathrm{~mm}$, GE Healthcare), after which the strip was rehydrated for $18 \mathrm{~h}$. After performing the IEF electrophoresis step for a total of $45,000 \mathrm{Vhrs}$, the IPG strip was first soaked in equilibration buffer consisting of $0.5 \mathrm{M}$ Tris $\mathrm{pH} 8.8,6 \mathrm{M}$ urea, 2\% SDS, and 30\% glycerol containing $100 \mathrm{mM}$ DTT for $15 \mathrm{~min}$, and then in equilibration buffer containing $110 \mathrm{mM}$ iodoacetamide (IAA) for $15 \mathrm{~min}$. For the second dimension, proteins were separated using sodium dodecyl sulfate-polyacrylamide gel electrophoresis (SDS-PAGE). Colloidal Coomassie blue staining was used to visualize the separated protein spots.

\subsection{Protein Quantification and Identification}

A total of nine stained gels were quantified using the Delta2D software according to the manufacturer's instructions. $p$-values $<0.05$ (Student's $t$-test) were taken as indicating a significant difference in expression. Among the matched protein spots $(n=113)$, those with significant quantitative difference were selected from each comparative analysis and identified (Control vs. DHT or FSK).

Proteins were identified by excising protein spots from 2DE gels for in-gel tryptic digestion using an in-gel tryptic digestion kit (Thermo Fisher Scientific, Rockford, IL, USA), according to the manufacturer's instructions. Briefly, excised gels were destained, reduced with TCEP (tris [2-carboxyethyl] phosphine), and alkylated with iodoacetamide (IAA). The alkylated gel pieces were dehydrated in 100\% acetonitrile (ACN) and digested with mass spectrometry (MS) grade trypsin for $12 \mathrm{~h}$ at $30^{\circ} \mathrm{C}$. Digested peptides were dried by evaporation using a vacuum concentrator and cleaned up for MS analysis using C18 spin columns (Thermo Fisher Scientific, Rockford, IL, USA).

Tryptic-digested peptides were analyzed using an Q Exactive hybrid quadrupoleorbitrap mass spectrometer (Thermo Fisher Scientific, Rockford, IL, USA) coupled to an Ultimate 3000 RSLC nano system (Thermo Fisher Scientific, Rockford, IL, USA). The tryptic peptides were loaded onto a trap column $(100 \mu \mathrm{m} \times 2 \mathrm{~cm})$ packed with Acclaim PepMap100 C18 resin, and eluted with a linear $5 \%$ to $30 \%$ gradient of solvent $\mathrm{B}(0.1 \%$ formic acid in $\mathrm{ACN}$ ) for $120 \mathrm{~min}$ at a flow rate of $300 \mathrm{~nL} / \mathrm{min}$.

The eluted peptides, separated using an EASY-Spray analytical column $(75 \mu \mathrm{m} \times 15 \mathrm{~cm}$; Thermo Fisher Scientific), were sprayed into a nano-ESI source at an electrospray voltage of $2.4 \mathrm{kV}$. Full MS scans were acquired over the m/z 300-2000 range with a mass resolution of 70,000 (at $m / z$ 200) using a Q Exactive Orbitrap mass analyzer operated using the top 10 data-dependent method. The AGC target value was $1.00 \times 10^{6}$. The ten most-intense peaks with a charge state $\geq 2$ were fragmented in the higher-energy collisional dissociation (HCD) cell with a normalized collision energy of $25 \%$, and tandem mass spectra were acquired in the Orbitrap mass analyzer with a mass resolution of 17,500 at $m / z 200$.

Database searching of all raw data files was performed using Proteome Discoverer software (Thermo Fisher Scientific, Rockford, IL, USA). The UniProt database was searched using SEQUEST-HT. The false-discovery rate (FDR) for peptide identification was evaluated by searching raw data against the corresponding reversed database. Database searching parameters included the following: up to two missed cleavages allowed for full tryptic digestion; precursor ion mass tolerance, 10 ppm; fragment ion mass tolerance, $0.02 \mathrm{Da}$; fixed modification for carbamidomethyl cysteine; and variable modifications for methionine oxidation and N/Q deamination. An FDR less than 1\% was obtained at the peptide level, and peptides were filtered with high confidence.

\subsection{Metabolite Sample Preparation and Identification}

Frozen pellets of cells treated with R1811 (10 nM) or FSK $(1 \mu \mathrm{M})$ for 3 and 24 h were thawed and kept on ice. The thawed pellets were suspended in $500 \mu \mathrm{L}$ of methanol, mixed by vortexing, and subsequently subjected to three freeze/thaw cycles. After centrifuging at $800 \times g$ for $1 \mathrm{~min}$, the supernatants were collected and transferred to new tubes. Next, the pellets remaining after the previous centrifugation step were suspended in $250 \mu \mathrm{L}$ of water, 
mixed by vortexing, and subjected to the same freeze/thaw process described above. All resulting supernatants were collected and dried using a concentrator.

The dried samples were reconstituted in $0.1 \%$ formic acid and applied to a Liquid Chromatograph-Tandem Mass Spectrometer (LC-MS/MS) consisting of an ExionLC system (AB Sciex, Foster City, CA, USA) and triple quad 5500+ system. Sample separation was achieved using Ultra high-performance LC with an Atlantis T3 column ( $3 \mu \mathrm{m}$, $2.1 \mathrm{~mm} \times 10 \mathrm{~mm}$; Waters, Milford, MA USA). A targeted profiling approach was applied using multiple reaction monitoring (MRM) of the MS system with reference standards for NADH, 4-hydroxynonenal, ATP, and lactic acid (Sigma-Aldrich). The following parameters were used for the MS system: turbo ion-spray voltage, $+5500 \mathrm{v}$; temperature, $500{ }^{\circ} \mathrm{C}$; curtain gas, 40 psi; CAD gas, 12 psi; and gas 1 and 2, 50 psi.

\subsection{Western Blot Analysis}

Treated VCaP cells were washed once with cold phosphate-buffered saline (PBS) and lysed by incubating in radioimmunoprecipitation (RIPA) lysis buffer $(20 \mathrm{mM}$ Tris- $\mathrm{HCl}$ $\mathrm{pH} 7.5,150 \mathrm{mM} \mathrm{NaCl}, 1 \% \mathrm{NP}-40,0.5 \%$ sodium deoxycholate, $1 \mathrm{mM}$ EDTA, $10 \mathrm{mg} / \mathrm{mL}$ leupeptin, $10 \mathrm{mg} / \mathrm{mL}$ aprotinin, $2 \mathrm{mM} \mathrm{NaVO}_{4}, 10 \mathrm{mM} \beta$-glycerophosphate, and 1 tablet protease inhibitor) for $1 \mathrm{~h}$ on ice. The lysates were centrifuged at $14,000 \mathrm{rpm}$ for $30 \mathrm{~min}$ at $4{ }^{\circ} \mathrm{C}$, and the supernatants were collected. The protein concentrations were determined using an enhanced BCA protein assay kit (Thermo Fisher Scientific, Rockford, IL, USA). Equal amounts of total protein from each sample were resolved by SDS-PAGE on $10 \%$ gels and transferred to PVDF (polyvinylidene difluoride) membranes.

After blocking with 50\% Odyssey Blocking Buffer in PBS containing 0.05\% Tween20 (PBS-T) for $1 \mathrm{~h}$ at room temperature, the membrane was incubated with anti-TUFM (Thermo Fisher Scientific, Rockford, IL, USA), anti-OXCT1 (Novus Biologicals), anti-ACPP (Novus Biologicals), or anti-LDHB (Abcam) primary antibody overnight at $4{ }^{\circ} \mathrm{C}$. The membrane was then washed four times with PBS-T for 5 min each and incubated with the appropriate secondary antibody (Santa Cruz Biotechnology) for $1 \mathrm{~h}$ at room temperature. Specific protein bands were detected using the $\mathrm{ECL}^{\mathrm{TM}}$ Prime western blotting detection reagent (GE Healthcare Life Sciences).

\subsection{Quantitative PCR Analysis}

The total RNA was extracted from androgen- or FSK-treated VCaP cells using the TRIzol Reagent (Favorgen Biotech Corp, Ping-Tung, Taiwan). A total of $1 \mu \mathrm{g}$ of RNA was reverse transcribed into cDNA using an AmpiGene cDNA Synthesis Kit (Enzo Biochem, New York, NY, USA). The resulting cDNA was quantified by real-time quantitative PCR using amfiSure qGreen Q-PCR master mix (GenDEPOT, Barker, TX, USA) and primers synthesized by Macrogen (Seoul, South Korea) as indicated in Table S1. The expression of target mRNAs was quantified using the $2^{-\Delta \Delta C T}$ method and normalized to the levels of GAPDH, which was used as an internal control.

\subsection{Analysis of the Progression-Free Interval and Gene Expression}

The RNA-seq TPM gene expression data for prostate cancer cell lines were downloaded from Dependency Map portal (https:/ / depmap.org, 7 September 2021), and gene expression profiles and clinical data were downloaded from The Cancer Genome Atlas (TCGA). Clinical outcomes for prostate adenocarcinoma (PRAD) of the TCGA study with Gleason score $\geq 6$ and the pooled normal and GTEx normal were used for comparison of gene expression pattern in tumor and normal and survival analyses [37].

In this latter study, the progression-free interval was recommended instead of the overall or disease-free survival since there were only 10 overall survival events out of 500 cases of PRAD in the TCGA study [37]. For comparisons of survival among patient groups, we divided samples according to the median mRNA expression level and included only samples that were greater than the upper quartile and lower than the lower quartile. 
Kaplan-Meier curves of two groups were compared using a log-rank test ( $p$-value $<0.05$ ) in the R survival package, survdiff, with the default parameters.

\section{Results}

3.1. Androgen- and PKA Signaling-Induced Changes in the Proteomic Profile of VCaP Cells and Identification of Differentially Expressed Proteins

AR signaling is active in CRPC regardless of androgen status. Importantly, however, the distinctive factors that mediate androgen-dependent and -independent AR signaling remain to be elucidated. To identify distinct proteins that mediate androgen-induced and androgen-independent signaling pathways, we first activated signaling pathways in VCaP cells by stimulation with DHT or FSK, respectively and then assessed protein expression using 2DE analysis. Differentially expressed proteins between proteomes obtained from control cells and DHT- or FSK-treated cells were assessed by performing a spot-by-spot analysis of the intensity of each protein spot in 2DE gels. For precise and reproducible experimental data, we performed three biological replicates in triplicate (Figure S1).

Overall, 113 proteins spots with different expression levels were detected between the control and DHT or FSK group, of which eight ultimately exhibited significant differences in density ( $>1.5$-fold changes in expression with $p<0.05)$. All eight differentially expressed proteins, shown in a representative 2DE gel (Figure 1), exhibited a clear and significant increase in response to DHT or FSK in three repeat experiments (Figure 2 and Table 1). Subsequent MS analyses unambiguously assigned identities to individual proteins. This analysis successfully identified three proteins that were altered in $\mathrm{VCaP}$ cells in response to DHT (androgen-induced signaling): LDHB (L-lactate dehydrogenase B chain), TUFM (elongation factor $\mathrm{Tu}$ ), and HNRNPH3 (heterogeneous nuclear ribonucleoprotein $\mathrm{H} 3$ ).

Table 1. The average density values of proteins that showed significant changes in expression in response to DHT or FSK.

\begin{tabular}{|c|c|c|c|c|c|c|c|}
\hline \multirow{2}{*}{ Comparison } & \multirow{2}{*}{ Protein Name } & \multicolumn{2}{|c|}{ Mean } & \multicolumn{2}{|c|}{ SD * } & \multirow{2}{*}{ Ratio } & \multirow{2}{*}{$p$-Value } \\
\hline & & Control & Treatment & Control & Treatment & & \\
\hline \multirow{3}{*}{ Control vs. DHT } & LDHB & 15.838 & 34.567 & 8.736 & 5.858 & 2.183 & 0.037 \\
\hline & TUFM & 7.120 & 13.901 & 1.554 & 3.078 & 1.952 & 0.027 \\
\hline & HNRNPH3 & 10.584 & 17.706 & 3.311 & 1.570 & 1.679 & 0.027 \\
\hline \multirow{5}{*}{ Control vs. FSK } & OXCT1 & 6.773 & 11.221 & 2.447 & 0.929 & 1.657 & 0.042 \\
\hline & ACPP & 12.637 & 28.735 & 2.900 & 3.534 & 2.274 & 0.004 \\
\hline & IMPDH2 & 5.937 & 18.424 & 3.404 & 1.666 & 3.103 & 0.005 \\
\hline & ССТ2 & 9.235 & 18.633 & 0.709 & 2.483 & 2.018 & 0.003 \\
\hline & HNRNPK & 7.573 & 33.052 & 5.482 & 6.157 & 4.365 & 0.006 \\
\hline
\end{tabular}

* SD, Standard Deviation.

Five proteins-OXCT1 (succinyl-CoA:3-ketoacid coenzyme A transferase 1), ACPP (prostatic acid phosphatase), IMPDH2 (inosine-5'-monophosphate dehydrogenase 2), CCT2 (T-complex protein 1subunit beta), and HNRNPK (heterogeneous nuclear ribonucleoprotein $\mathrm{K}$ ), were found to be specifically increased in VCaP cells in response to FSK. Representative MS/MS spectra of protein spots are shown in Figure S2, and the number of unique peptides, molecular weights, and isoelectric points for each protein, derived from MS analysis, are shown in Table S2.

To investigate the functional role of identified proteins, we performed a Gene Ontology (Go) analysis of their cellular localization (cellular component) and biological role (biological process). This information is summarized in Table S2. Interestingly, this analysis revealed that all identified proteins are involved in metabolic processes. Notably, metabolic reprogramming is known to be associated with re/activation and antagonism of AR signaling, which, in turn, drives CRPC progression [38]. Further metabolic process information was obtained for major molecules associated with the identified proteins (Please see Section 3.3). 


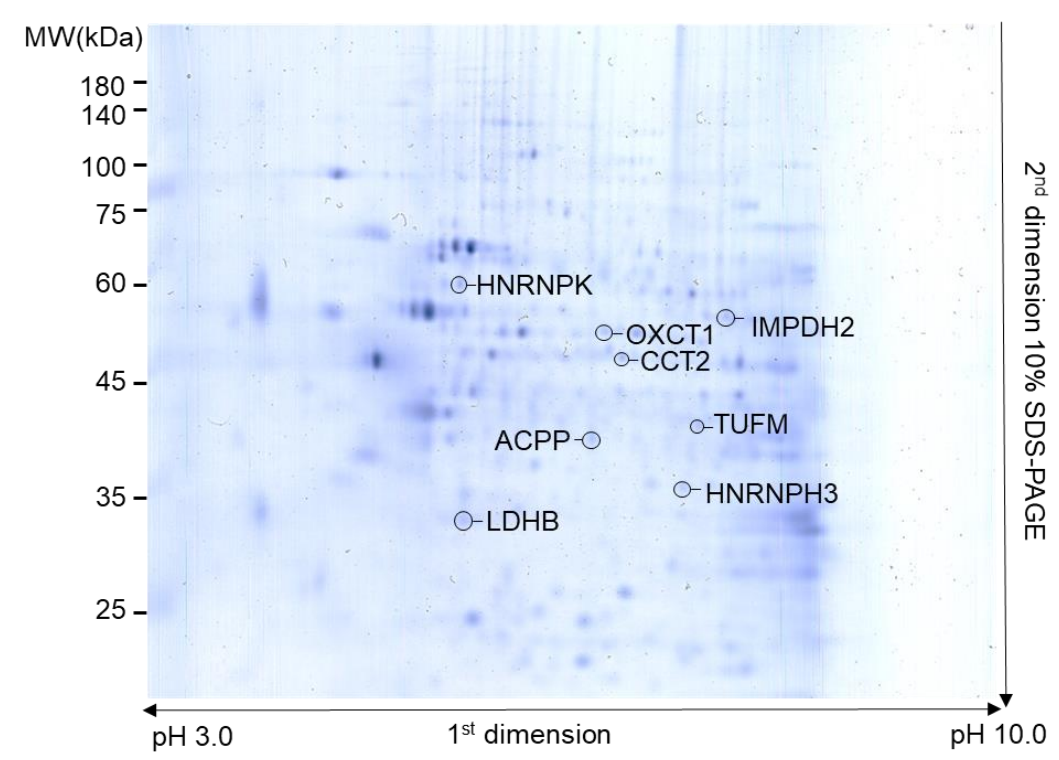

Figure 1. 2DE analysis and identification of protein spots showing significant changes in expression between the control group and DHT-or FSK-treated groups. Representative gel showing eight protein spots with significant changes in expression (density) among DHT-, FSK-treated groups, and the control group as well as the identification of proteins by MS analysis.

(a)
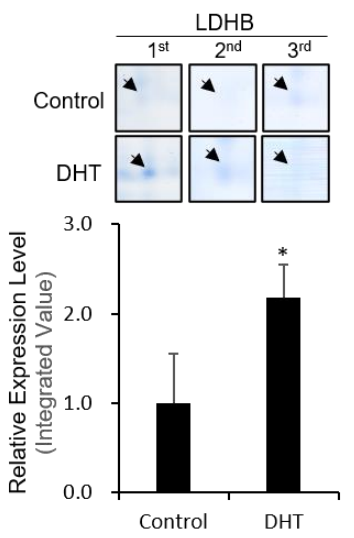

(b)
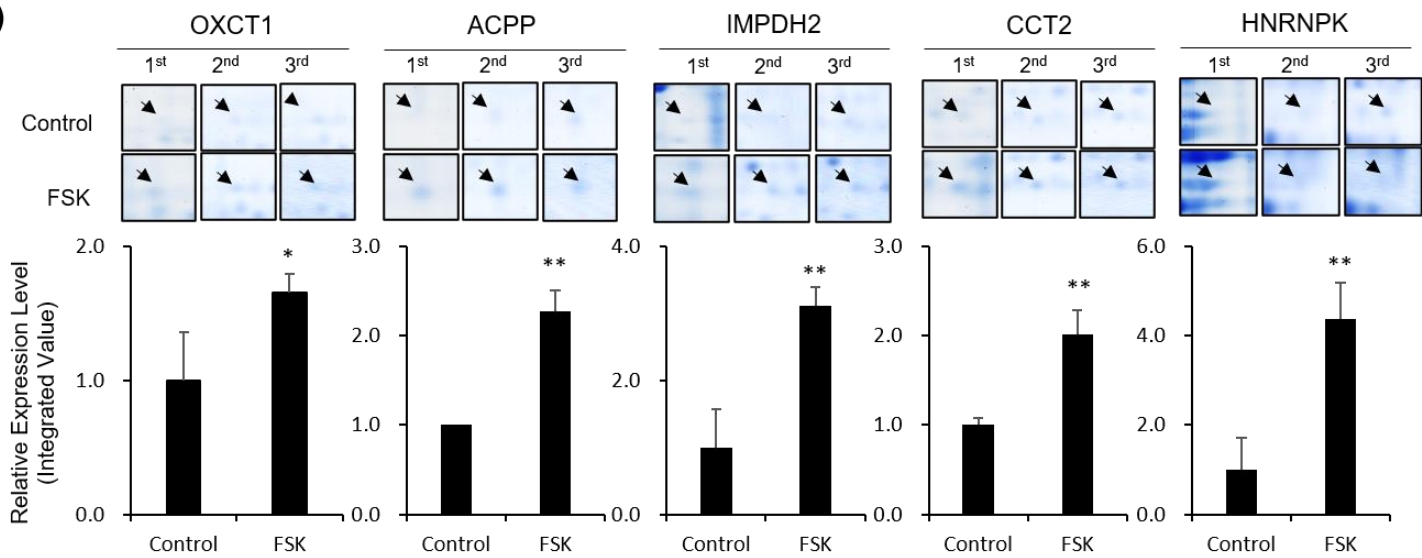

Figure 2. Comparative expression levels of the identified protein spots. Protein spots and the relative expression levels of proteins regulated by DHT (a) and FSK (b) from 2DE analysis. Significantly regulated proteins exhibiting between-group changes of 1.5 -fold or more $\left({ }^{*} p<0.05,{ }^{* *} p<0.01\right)$ are presented. The values were calculated based on spot densities obtained using PDQuest. The data obtained from the mean \pm standard deviation (SD) of three independent experiments are presented as fold changes. 


\subsection{Validation of Androgen- and PKA Signaling-Specific Differentially Expressed Proteins}

Next, using quantitative RT-PCR, we further confirmed the DHT- or FSK-induced increases in expression of all eight proteins at the mRNA level, suggesting a pathwayspecific role of DHT- and FSK-induced proteins in VCaP cells (Figure 3).

(a)

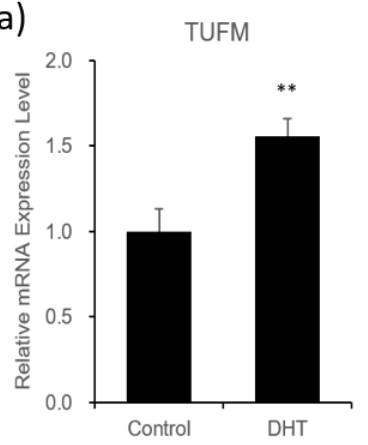

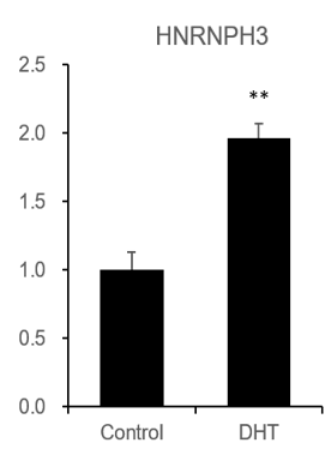

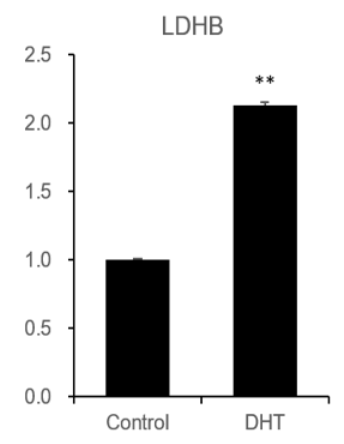

(b)
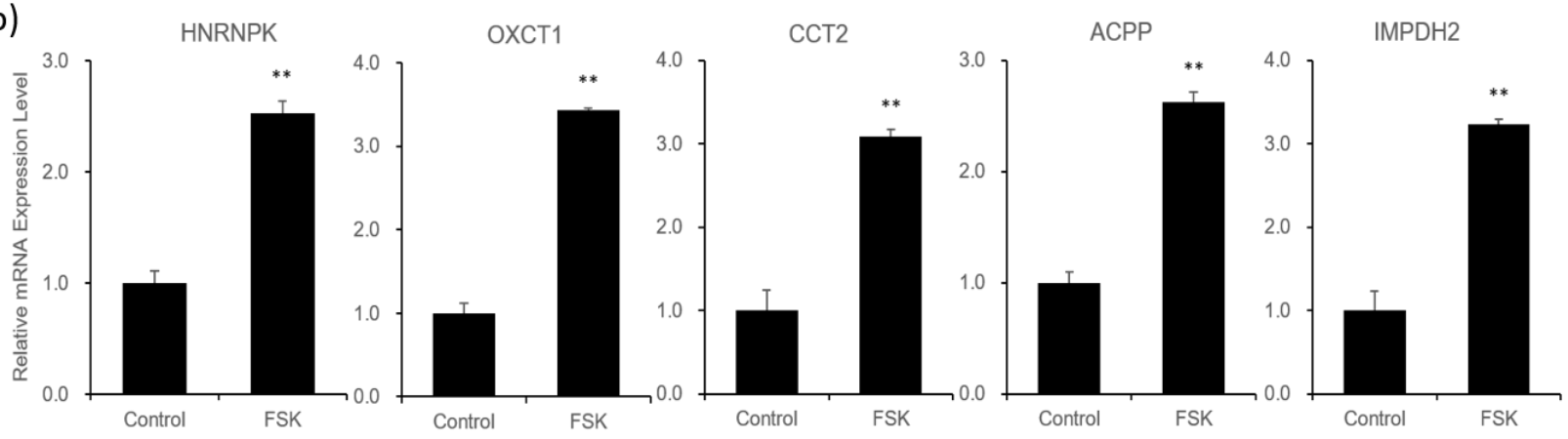

Figure 3. Relative mRNA expression levels of identified proteins that are significantly induced by androgen and PKA signaling pathways. Changes in the mRNA level of proteins significantly modulated by DHT (a) or FSK (b), as determined by qRT-PCR analysis. All data obtained from the means \pm SD of three independent experiments are presented as fold changes $(* * p<0.01)$.

To extend our knowledge of the specific expression of eight proteins in a prostate cancer cell with amphicrine features, like $\mathrm{VCaP}$, we determined the endogenous expression level of proteins in five different prostate cancer cell lines from the Dependency Map portal (https: / / depmap.org, accessed on 7 September 2021) along with the expression of AR and neuroendocrine biomarker, synaptophysin (SYP), which shows an amphicrine feature [36]. All eight proteins were observed in $\mathrm{VCaP}$ cells as well as other prostate cancer LNCaP, 22RV1, MDAPCA2B, and PC3 cells with a different expression level (Figure S3). TUFM and $\mathrm{ACPP}$, which are frequently associated with prostate cancer, and two metabolic enzymes, LDHB and OXCT1, were further confirmed at the protein level in DHT (androgen)- and FSK (PKA signaling)-stimulated VCaP cells by immunoblotting (Figure 4a,b).

TUFM is a key factor in the translational expression of mitochondrial DNA, playing an important role in the control of mitochondrial function, whereas ACPP is a glycoprotein that is mainly synthesized and secreted by glandular epithelial cells of the prostate. The expression of both ACPP and PSA mRNA is significantly elevated in prostatic carcinoma compared with that in benign prostatic hyperplasia [39-41]. In addition, TUFM is upregulated at the protein level in prostate cancer [42,43], and ACPP has been used as a diagnostic and prognostic marker together with prostate-specific antigen (PSA) for prostate cancer.

LDHB, induced by androgen-specific signaling, is a well-known metabolic enzyme involved in lactate production, which leads to bypassing of oxidative phosphorylation, especially in glycolic cancer cells $[44,45]$. It has been proposed that pancreatic cancer [46] and breast cancer [47] patients with lower LDHB expression are more likely to show positive responses to treatment, and LDHB has frequently been proposed as a diagnostic and prognostic marker in prostate cancer $[48,49]$. In this study, we found increased expression 
of LDHB in androgen-stimulated VCaP cells (Figure 4a, right), supporting the prognostic and diagnostic value of LDHB as well as its role as a therapeutic target in prostate cancer.

(a)
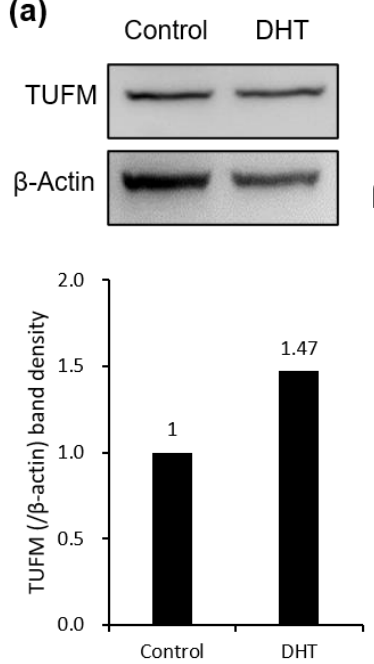
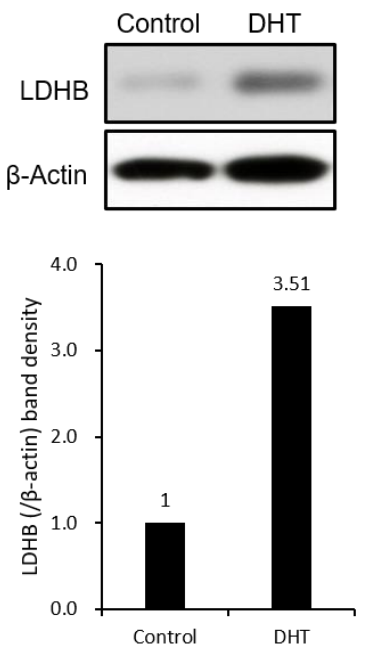

(b)
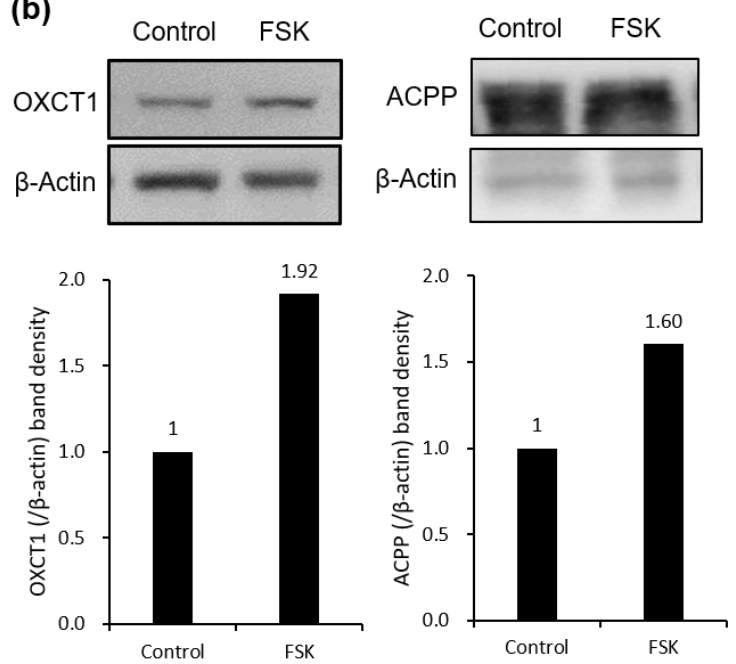

Figure 4. Confirmation of significant changes in the protein expression level. The levels of proteins found to be significantly regulated by DHT (a) and FSK (b) in our 2DE analysis were confirmed by western blot analysis. Results are the representative of three independent experiments and fold change of expression was labeled.

OXCT1, an enzyme that catalyzes the reversible transfer of CoA from succinyl-CoA to acetoacetate in mitochondrial membranes [50], is considered a therapeutic target in cancer by virtue of its regulation of ketone bodies [51]. OXCT1 expression is increased in LNCaP-SF cells, an androgen-independent LNCaP cell line derivative, as well as in high-grade prostate cancers relative to normal and low-grade samples [52]. In this study, OXCT1 expression was induced by PKA signaling at both the mRNA and protein levels in $\mathrm{VCaP}$ cells (Figures $3 \mathrm{~b}$ and $4 \mathrm{~b}$ ). As is the case in androgen-independent cell lines, OXCT1 is thought to contribute to the metabolic processing involved in the development of advanced prostate cancer stages.

\subsection{Androgen- and PKA Signaling-Induced Metabolic Alterations in VCaP Cells}

Some of the differentially expressed proteins identified in VCaP cells are involved in the metabolism, including LDHB, which was increased in androgen-induced signaling only, and IMPDH2 and OXCT1, which were increased in FSK-induced signaling only, leading us to further validate signaling-specific metabolic alterations. To this end, we treated $\mathrm{VCaP}$ cells with androgen (10 nM R1881) or FSK $(1 \mu \mathrm{M})$ for 3 or $24 \mathrm{~h}$, and after harvesting cells, we measured the metabolites by MS analysis (Figure 5).

Dysregulated metabolism for increased energy production to provide enough proliferation and growth is one of the hallmarks of cancer cells. Prostate cancer has a unique metabolic feature with specific metabolic and energetic phenotypes according to the stage of cancer progression [53], such as the absence of the Warburg effect observed in primary prostate cancer. The understanding of the relationship between these distinctive metabolic features and AR signaling in PCa is crucial [38].

Serum-starved VCaP cells showed a gradual decrease over time in the intracellular concentrations of ATP $\left([\mathrm{ATP}]_{\mathrm{i}}\right)$, lactic acid ([lactic acid $\left.]_{\mathrm{i}}\right)$, hydroxynonenal ([hydroxynonenal $\left.]_{\mathrm{i}}\right)$, and citric acid ([citric acid $\left.]_{\mathrm{i}}\right)$, and an increase in NADH concentration in the cell ([NADH $]_{\mathrm{i}}$ ) after treatment for 3 and $24 \mathrm{~h}$ compared with the pretreatment values ( $\mathrm{t}_{0}$ ) (Figure $5 \mathrm{a}$ ). Both androgen- and FSK-induced signaling reduced $[\mathrm{ATP}]_{\mathrm{i}}$ and increased [hydroxynonenal $]_{\mathrm{i}}$ at $3 \mathrm{~h}$ (Figure $5 \mathrm{~b}$ ); in contrast, [lactic acid] $]_{\mathrm{i}}$ was increased at $3 \mathrm{~h}$ and came back to a similar level of control at $24 \mathrm{~h}$ only in androgen-stimulated cells, while $[\mathrm{NADH}]_{\mathrm{i}}$ was increased only in FSK-stimulated cells at $3 \mathrm{~h}$. 
(a)

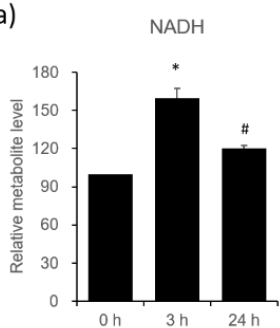

(b)

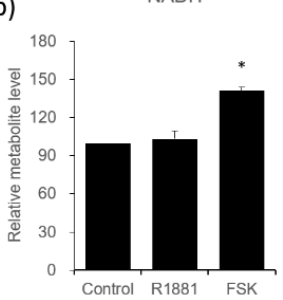

(c)

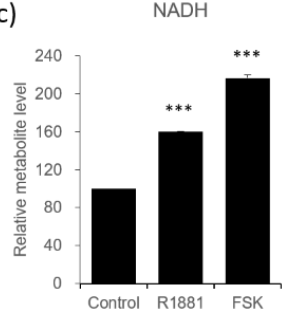

ATP

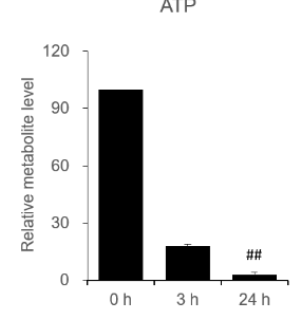

ATP

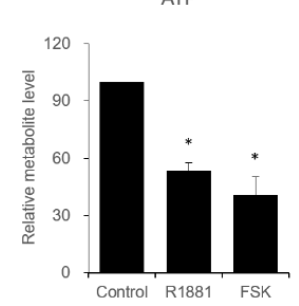

ATP

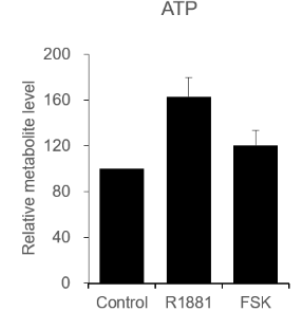

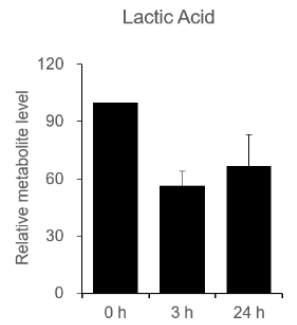

Lactic Acid
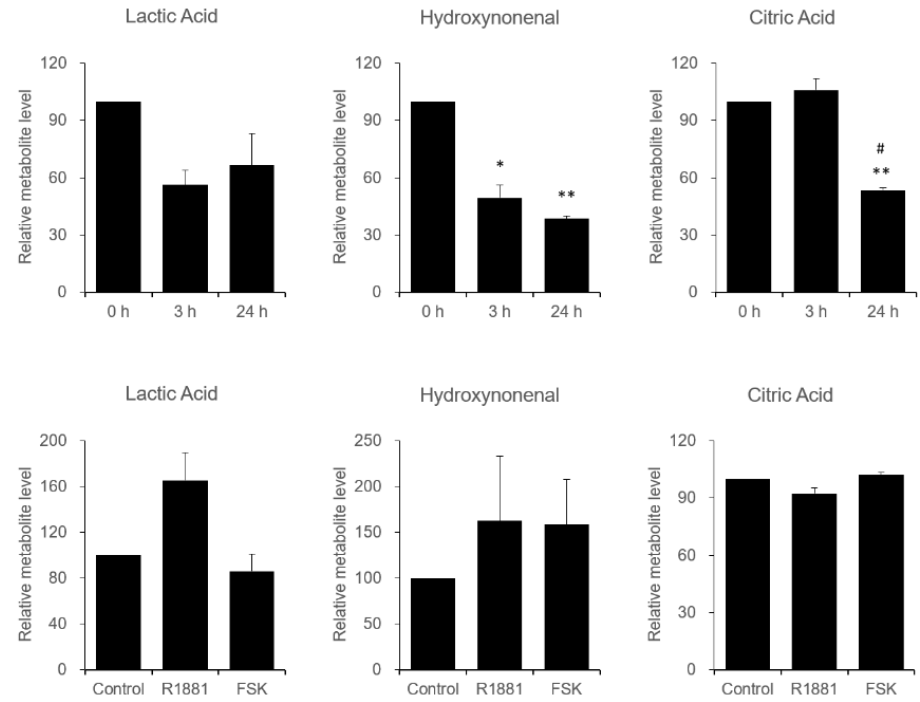
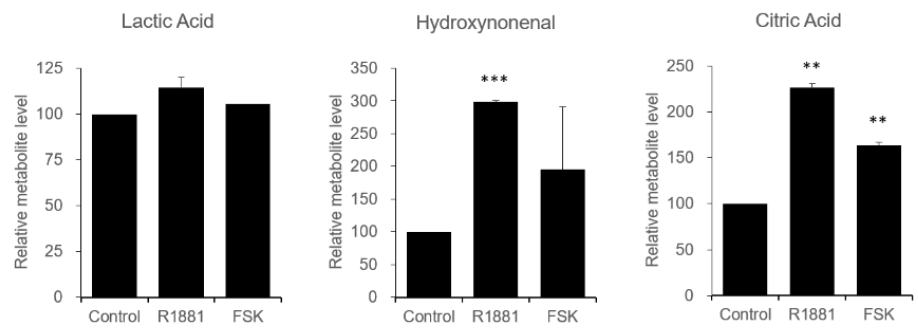

Figure 5. Determination of the differential expression levels of metabolites, NADH, ATP, lactic acid, hydroxynonenal, and citric acid in VCaP cells. Metabolite concentrations modulated by R1881 and FSK were measured in VCaP cells at 3 and $24 \mathrm{~h}$. (a) The time course of changes in metabolites, measured in serum-starved VCaP cells. (b) Changes in metabolites associated with androgen or PKA signaling pathways, measured at $3 \mathrm{~h}$. (c) Changes in metabolites associated with androgen or PKA signaling pathways, measured at $24 \mathrm{~h}$. Statistical significance is indicated as follows: (a): ${ }^{*} p<0.05,{ }^{* *} p<0.01$ when compared with non-starved control group, ${ }^{\#} p<0.05,{ }^{\#} p<0.01$ when compared with 3-h serum-starved group. (b): ${ }^{*} p<0.05$ when compared with untreated control group. (c): ${ }^{* *} p<0.01,{ }^{* *} p<0.001$ when compared with the untreated control group.

Interestingly, $[\text { hydroxynonenal }]_{\mathrm{i}},[\mathrm{ATP}]_{\mathrm{i}}$, and $[\text { citric acid }]_{\mathrm{i}}$ were increased in androgenstimulated cells at $24 \mathrm{~h}$ (Figure 5c), which implies a role of androgen-induced signaling on metabolic pathways through proteins, including LDHB. Alteration of [lactic acid $]_{i},[\text { ATP }]_{i}$, $[\mathrm{NADH}]_{i}$, and [citric acid $]_{\mathrm{i}}$ in a time course manner, suggested a role of androgen on energy metabolism, particularly ATP synthesis, through oxidative phosphorylation in androgeninduced signaling. $[\mathrm{ATP}]_{\mathrm{i}},[\mathrm{NADH}]_{i}$, and [hydroxynonenal $]_{\mathrm{i}}$ showed a distinct energy metabolic regulation through fatty acid synthesis pathways in FSK-induced VCaP cells.

In terms of the energy metabolism, androgen signaling might be beneficial for the efficiency of ATP generation through two different pathways: oxidative phosphorylation, mediated by androgen binding, and the fatty acid synthetic pathways, specifically facilitated by FSK-induced, PKA-mediated activation. The metabolism in CRPC is mainly studied from the standpoint of overcoming androgen castration. Here, we provide evidence for distinct pathways involved in the acquisition of androgen signaling in $\mathrm{VCaP}$ cells: direct AR activation by androgen binding and indirect AR activation via PKA.

\subsection{Clinical Correlations of Proteins That Are Significantly Altered by Androgen- or PKA Signaling Pathways}

Androgen directly binds to the AR, a nuclear receptor that signals by regulating androgen-response element-dependent gene expression. In our study, eight proteins were altered within $3 \mathrm{~h}$ of DHT or FSK stimulation, exhibiting specific responses to the two 
agents. An assessment of alterations in metabolites in response to R1881 and FSK exposure showed significant common effects on $[\mathrm{ATP}]_{\mathrm{i}}$ but distinct effects on a few metabolites. To gain insight into whether these eight proteins are involved in prostate cancer progression and malignancy, we obtained prostate cancer expression data from the TCGA database (http://www.cbioportal.org, accessed on 12 Feburary 2021) and further analyzed the correlation between progression-free interval and the expression of each protein.

This analysis was conducted on a cohort in which all tumors had a Gleason Score of 6 or higher demonstrating the worse and poor prognosis [54-56]. VCaP cells display an amphicrine profile, which is the co-expression of the AR, AR target genes and neuroendocrine (NE) genes and AR and classical NE biomarker, SYP [36]. Thus, AR and SYP were included for the expression analysis along with eight proteins. As shown in Figure 6a, changes of expression levels of eight proteins were observed in tumors compared with normal tissue, and the expression levels of AR and SYP were increased implying that clinical samples used in TCGA analysis have an amphicrine phenotype.

(a)

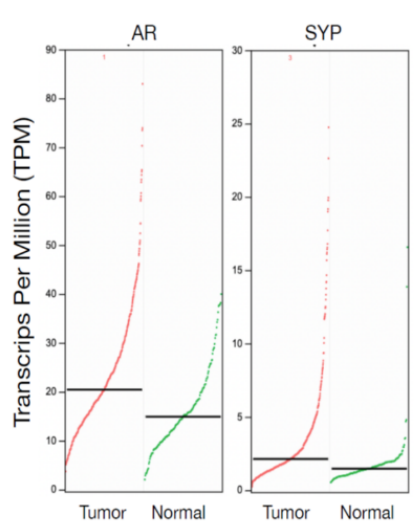

(b)

(d)
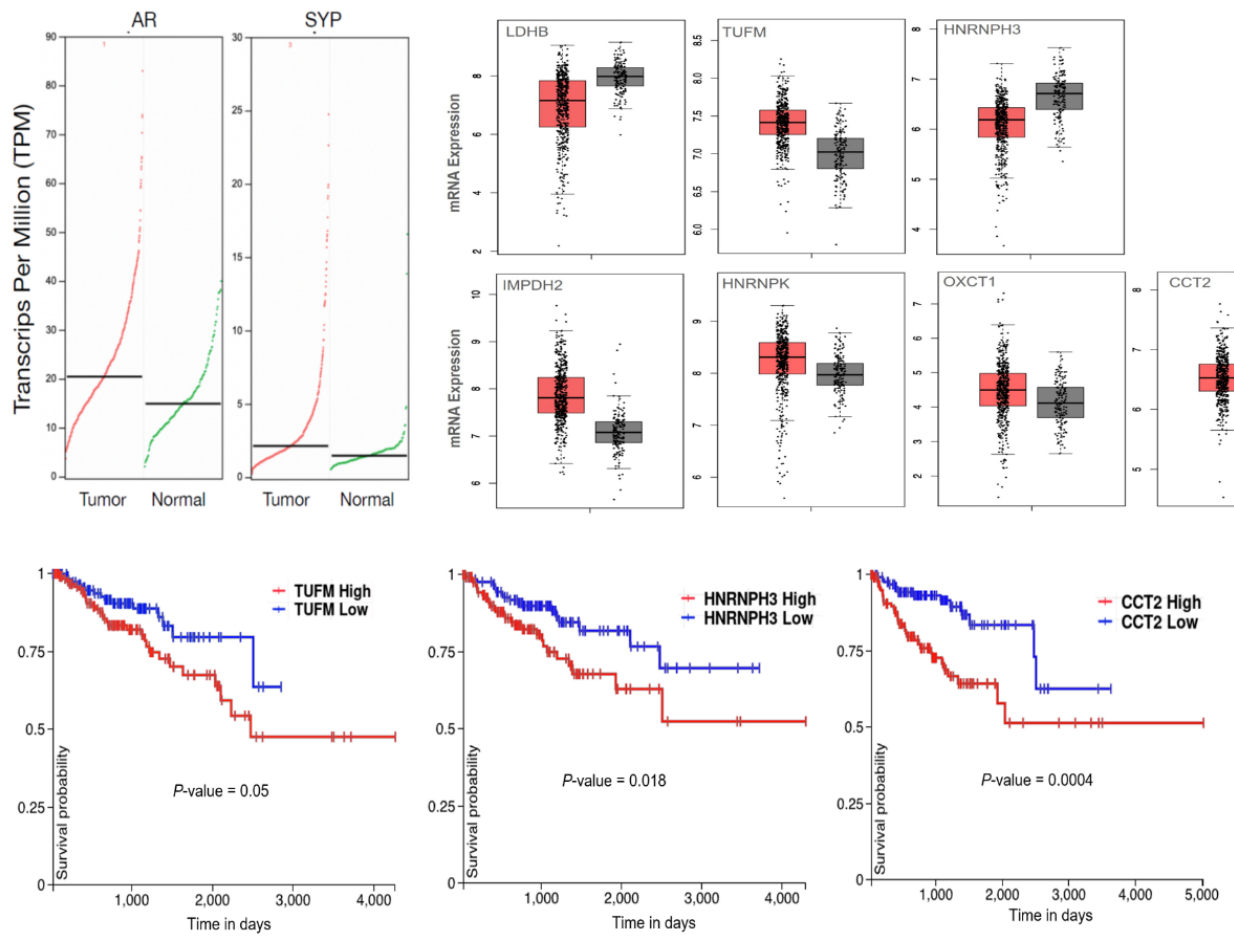

(c)

(c) Gleason score
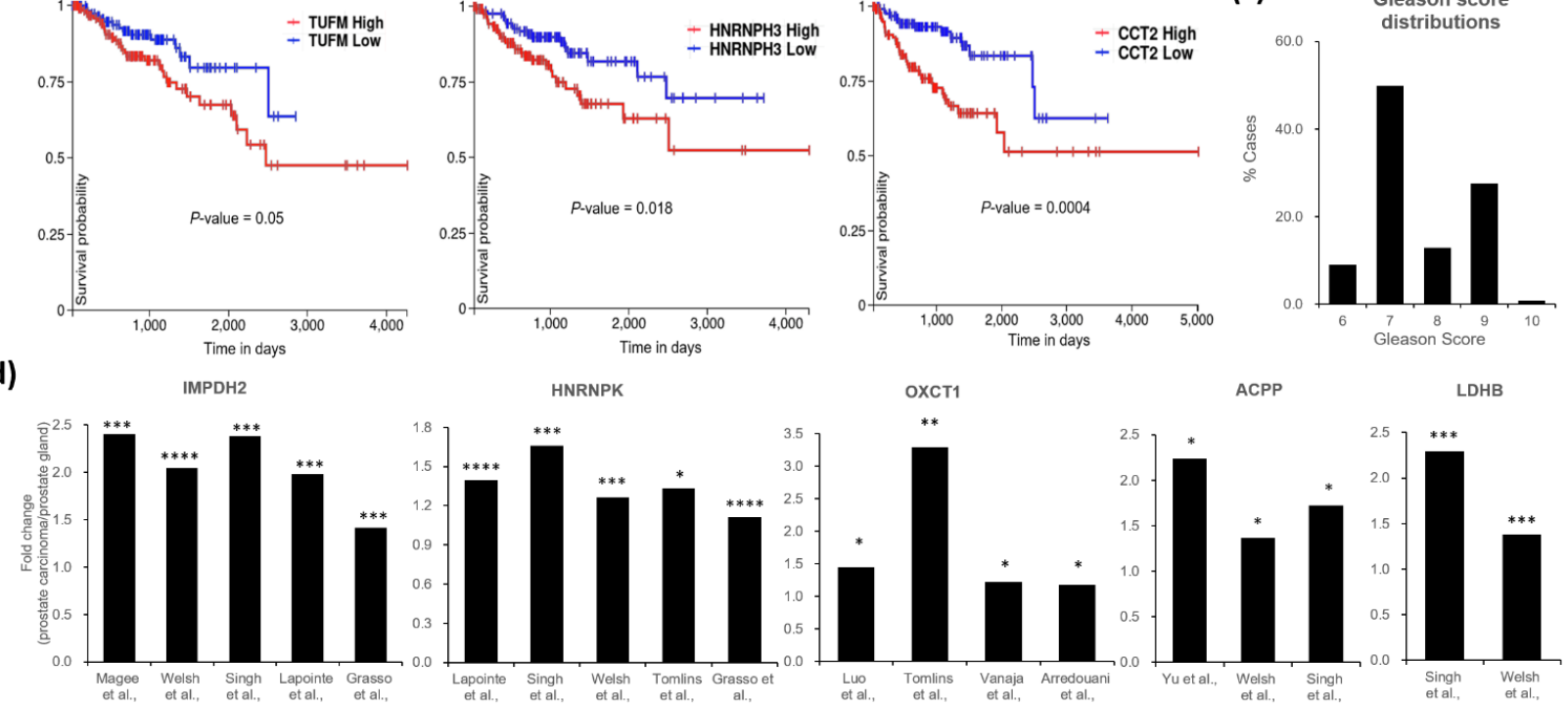

ACPP

LDHB

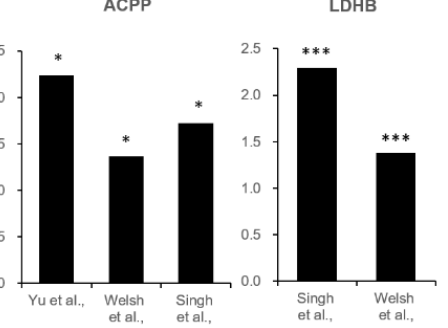

Figure 6. Protein expression and progression-free interval in prostate cancer patients. (a) Dot plots show the profiling of AR and SYP gene expression across tumor and paired normal samples, with each dot representing a distinct tumor or normal samples (left), and the relative expression of eight genes (right) was represented in normal tissues versus tumor tissues with a Gleason score $\geq 6$. (b) Kaplan-Meier curves show that changes in the mRNA expression of DHT- and FSK-regulated proteins are associated with clinical outcomes in samples from the TCGA PRAD database $(n=550 ; \log$-rank $p$-value $<0.05)$. (c) Gleason score distribution was represented from patients used in this study. (d) Differences in gene expression were quantified as fold changes in prostate carcinomas, including hormone refractory prostate cancer and metastatic prostate cancer samples compared with prostate gland samples from various datasets [57-66] ${ }^{*} p<0.05,{ }^{* *} p<0.01,{ }^{* * *} p<0.001$, $* * * * * 0.0001)$. 
In addition, the expression levels of three proteins-TUFM, and HNRNPH3 from the DHT-specific proteome, and CCT2 from the FSK-specific proteome-were related to the progression-free interval in prostate cancer patients (Figure 6b). The increased expression levels of TUFM, HNRNPH3, and CCT2 were significantly correlated with survival without progression, suggesting a possible role for each protein in CRPC development especially with a higher Gleason score (Figure 6b,c).

In addition to TCGA data analysis, we also analyzed the expression levels of the five proteins from the DHT-specific protein, LDHB as well as FSK-specific proteins, IMPDH2, HNRNPK, OXCT1, and ACPP in protein carcinomas, including hormone refractory prostate cancer and metastatic prostate cancer samples in several publicly available datasets. Interestingly, these proteins showed significantly greater expression in prostate tumor tissues than in normal or adjacent normal tissues (Figure 6d), suggesting that signaling-specific proteins identified in VCaP cells are relevant in the context of advanced prostate cancer.

\section{Discussion}

In CRPC, one mechanism of resistance against hormone deprivation and progression is thought to be the expression of truncated AR variants. These AR variants lack a C-terminal domain, thus, resulting in androgen-independent signaling [19,67]. Using LNCaP cells, which express mutant AR, we stimulated androgen-induced or PKA-induced AR signaling by treating cells with DHT or FSK, respectively, and assessed differences in the proteomes between the two treatments using 2DE [35]. Here, we have studied differential proteome expression using VCaP cells, which express both wild-type AR and AR splicing variants.

This analysis identified eight signaling-specific proteins, three from the androgenspecific proteome and five from the PKA-induced proteome, all of which were subsequently validated in MS analyses and cell-based studies (Figures 2-4). Interestingly, most proteins that showed significantly different changes in expression are known to be involved in metabolic processes. A further investigation of the involvement those of proteins in the metabolic transformation, which plays an important role in prostate cancer progression, revealed alterations in levels of the metabolites, ATP, NADH, lactic acid, hydroxynonenal, and citric acid in response to R1881 or FSK. Some metabolites were altered in common, whereas others were altered in an agonist-specific manner (Figure 5).

Lactate dehydrogenase (LDH) is the primary metabolic enzyme that converts pyruvate to lactate, and vice versa, making it an important player in the cancer metabolism. LDHB is found at the highest densities in mitochondria; and, in normoxic cells, mitochondrial LDHB converts lactate to pyruvate. This lactate-derived pyruvate can then be used as fuel for the TCA cycle, oxidative phosphorylation, and mitochondrial respiration $[68,69]$.

Although the absence of the LDHB was not found in LNCaP but in LNCaP-LN3 cells at the protein and mRNA level [70], and the loss of LDHB increased the tumorigenicity of prostate cancer cells [71], it has been shown that increased LDHB activity and the Warburg effect are required for tumor progression and metastases in a preclinical model of prostate cancer [72]. Consistent with this, LDHB expression is highly elevated in lung cancer [73] and breast cancer $[47,74]$. Under acidic conditions with high lactate, androgen may induce an increase in LDHB in VCaP cells, resulting in a decrease in lactic acid and an increase in pyruvate for oxidative phosphorylation and ATP generation; NAD is also increased under these conditions, leading to an increase in NADH (Figure 5). In fact, LDHB was shown to control tumor progression and cancer cell proliferation through modulation of lysosome activity and autophagy [75].

We also observed upregulated IMPDH2 protein (Figure 2) and increased NADH (Figure 5) in FSK-stimulated VCaP cells. IMP dehydrogenase (IMPDH) catalyzes the oxidation of IMP to XMP, with the concomitant reduction of NAD to NADH, playing a role as a nucleotide biosynthetic enzyme; it also acts as a transcription factor to regulate proliferationassociated genes $[76,77]$. Interestingly, $[\mathrm{NADH}]_{\mathrm{i}}$ was higher in FSK-stimulated cells than in androgen-stimulated cells at both 3 and 24 h (Figure 5), whereas [hydroxynonenal] $]_{i}$ was 
less at $24 \mathrm{~h}$ in FSK-stimulated cells than in androgen-stimulated cells, implying a role for $\mathrm{NADH}$ in the peroxidation of lipids for cellular energy metabolism and redox balance.

Importantly, candidate proteins, IMPDH2, HNRNPK, OXCT1, ACPP, and LDHB, were highly expressed in progressive prostate cancer patients (Figure 6d, and the elevated expression of TUFM, HNRNPH3, and CCT2 was significantly associated with progression-free interval in prostate cancer patients diagnosed with a Gleason Score 6 or higher (Figure 6b, supporting the inference that the identified proteins might contribute to prostate cancer progression. In addition to previous molecular studies on the enhanced expression of IMPDH2 [78-80], HNRNPK [81], OXCT1 [52], ACPP [39-41], LDHB [82], TUFM [42,43], HNRNPH3 [83], and CCT2 ([84-86], dysregulated expression of those proteins may be useful for clinicopathological features of prostate cancer patients. In terms of treatment resistance, metastatic CRPC has been studied for better therapeutic options and overcoming the resistance.

In one of these approaches, Dr. Morrissey and Dr. Nelson and colleagues characterized metastatic CRPC and cell lines into five phenotypes depending on the AR or NE genes $[87,88]$. According to their phenotypes, $\mathrm{VCaP}$ cell lines are considered as amphicrine (AMPC) expressing both AR and NE genes, which are used to define the molecular characteristics of samples used for expression analysis in cell lines and clinical samples (Figure $6 \mathrm{a}, \mathrm{b}$ and Figure S3). Here, we report eight proteins altered by androgen-induced or PKA-induced signaling; however, the detailed mechanism is not clear, and further investigation will be required to elucidate how they contribute to AMPC phenotype and drug response in prostate cancer cells.

Taken together, our findings highlight eight proteins specific to androgen or PKA signaling proteomes that were significantly regulated and validated in cells and tissues. In addition, we further identified a significant association of candidate proteins with metabolic processes. Aberrant protein levels may reflect molecular changes regulated by androgen and/or PKA signaling pathways in the context of AR signaling. Thus, our findings provide helpful insights into prostate cancer progression generally and the relationship between intracellular factors and AR signaling cascades, specifically.

Supplementary Materials: The following are available online at https:/ /www.mdpi.com/article/ 10.3390/biomedicines9101404/s1, Figure S1: 2DE analysis of proteins from VCaP cells. Proteome analysis of VCaP prostate cancer cells treated with androgen (10 nM DHT) or forskolin (1 $\mu \mathrm{M} \mathrm{FSK})$ by $2 \mathrm{DE}$ analysis are represented. Proteins were resolved by IEF over the pI range 3-10, followed by $10 \%$ SDS-PAGE, and visualized with coomassie colloidal blue staining in triplicate. Figure S2: Representative MS/MS spectra of proteins identified using SEQUEST-HT. The representative spectrum was represented from the identified peptide ELLTEFGYK corresponding to TUFM, VHIDIGADGR corresponding to HNRNPH3, FIIPQIVK corresponding to the LDHB, DLAGSIIGK corresponding to HNRNPK, AGNVIFRK corresponding to OXCT1, LAVEAVLR corresponding to CCT2, FLNESYK corresponding to ACPP, and DRVRDVFEAK corresponding to IMPDH2. Figure S3. mRNA expression in different prostate cancer cell lines. The expression level of genes significantly regulated by androgen (LDHB, TUFM, and HNRNPH3) or forskolin (IMPDH2, HNRNPK, OXCT1, CCT2, and ACPP) was determined in LNCaP, VCaP, 22RV1, MDAPCA2B, and PC3 cells along with the expression of AR and the neuroendocrine biomarker, SYP. The expressions are Log2 transformed, using a pseudo-count of 1. Table S1: The oligonucleotide primers used in the study. Sequences of the oligonucleotide primers used in quantitative PCR analysis are shown. Table S2: List of proteins identified by MS analysis. Proteins with significant expression changes were identified by MS analysis and functional information including cellular components and the biological process is described.

Author Contributions: Conceptualization, H.-J.Y., B.-C.Y. and J.-K.M.; methodology, B.-C.Y. and J.-K.M.; validation, J.-M.P., B.-S.S. and J.-K.K.; formal analysis, J.-K.K., J.-M.P. and B.-S.S.; investigation, J.-K.M.; resources, J.-K.M.; data curation, H.-J.Y. and J.-K.M.; writing-original draft preparation, H.-J.Y., B.-C.Y., J.-K.K., B.-S.S. and J.-K.M.; writing-review and editing, H.-J.Y. and J.-K.M.; visualization, H.-J.Y. and J.-K.M.; supervision, J.-K.M.; funding acquisition, H.-J.Y. and J.-K.M. All authors have read and agreed to the published version of the manuscript. 
Funding: This research was funded by Basic Science Research Program through the National Research Foundation of Korea (NRF) funded by the Ministry of Education (2015R1C1A1A02036315 and 2018R1A2B6001241) and National Cancer Center (NCC-2110521).

Institutional Review Board Statement: Not applicable.

Informed Consent Statement: Not applicable.

Acknowledgments: We would like to acknowledge Seho Cha and Giyoon Nam for assistance in the gel image analysis. We thank Won-Bok Kim for assistance in 2DE and Su-Yeong Wi and Md-Abu Rayhan for assistance in the western blot analysis. We would also like to thank the Proteomics Core Facility at the National Cancer Center in Korea, which provided mass spectrometry services.

Conflicts of Interest: The authors declare no conflict of interest.

\section{References}

1. Siegel, R.L.; Miller, K.D.; Jemal, A. Cancer Statistics, 2020. CA Cancer. J. Clin. 2020, 70, 7-30.

2. Shen, H.C.; Balk, S.P. Development of Androgen Receptor Antagonists with Promising Activity in Castration-Resistant Prostate Cancer. Cancer Cell 2009, 15, 461-463. [CrossRef] [PubMed]

3. Attard, G.; Richards, J.; de Bono, J.S. New Strategies in Metastatic Prostate Cancer: Targeting the Androgen Receptor Signaling Pathway. Clin. Cancer Res. 2011, 17, 1649-1657. [CrossRef] [PubMed]

4. Chandrasekar, T.; Yang, J.C.; Gao, A.C.; Evans, C.P. Targeting Molecular Resistance in Castration-Resistant Prostate Cancer. BMC Med. 2015, 13, 206. [CrossRef]

5. Mitsiades, N. A Road Map to Comprehensive Androgen Receptor Axis Targeting for Castration-Resistant Prostate Cancer. Cancer Res. 2013, 73, 4599-4605. [CrossRef]

6. Hettel, D.; Sharifi, N. HSD3B1 Status as a Biomarker of Androgen Deprivation Resistance and Implications for Prostate Cancer. Nat. Rev. Urol. 2018, 15, 191-196. [CrossRef]

7. Stanbrough, M.; Bubley, G.J.; Ross, K.; Golub, T.R.; Rubin, M.A.; Penning, T.M.; Febbo, P.G.; Balk, S.P. Increased Expression of Genes Converting Adrenal Androgens to Testosterone in Androgen-Independent Prostate Cancer. Cancer Res. 2006, 66, $2815-2825$. [CrossRef]

8. Geller, J.; Albert, J.D.; Nachtsheim, D.A.; Loza, D. Comparison of Prostatic Cancer Tissue Dihydrotestosterone Levels at the Time of Relapse Following Orchiectomy Or Estrogen Therapy. J. Urol. 1984, 132, 693-696. [CrossRef]

9. Mohler, J.L.; Gregory, C.W.; Ford, O.H., III; Kim, D.; Weaver, C.M.; Petrusz, P.; Wilson, E.M.; French, F.S. The Androgen Axis in Recurrent Prostate Cancer. Clin. Cancer Res. 2004, 10, 440-448. [CrossRef]

10. Gregory, C.W.; Johnson, R.T., Jr.; Mohler, J.L.; French, F.S.; Wilson, E.M. Androgen Receptor Stabilization in Recurrent Prostate Cancer is Associated with Hypersensitivity to Low Androgen. Cancer Res. 2001, 61, 2892-2898.

11. Montgomery, R.B.; Mostaghel, E.A.; Vessella, R.; Hess, D.L.; Kalhorn, T.F.; Higano, C.S.; True, L.D.; Nelson, P.S. Maintenance of Intratumoral Androgens in Metastatic Prostate Cancer: A Mechanism for Castration-Resistant Tumor Growth. Cancer Res. 2008, 68, 4447-4454. [CrossRef]

12. Holzbeierlein, J.; Lal, P.; LaTulippe, E.; Smith, A.; Satagopan, J.; Zhang, L.; Ryan, C.; Smith, S.; Scher, H.; Scardino, P.; et al. Gene Expression Analysis of Human Prostate Carcinoma during Hormonal Therapy Identifies Androgen-Responsive Genes and Mechanisms of Therapy Resistance. Am. J. Pathol. 2004, 164, 217-227. [CrossRef]

13. Mitsiades, N.; Sung, C.C.; Schultz, N.; Danila, D.C.; He, B.; Eedunuri, V.K.; Fleisher, M.; Sander, C.; Sawyers, C.L.; Scher, H.I. Distinct Patterns of Dysregulated Expression of Enzymes Involved in Androgen Synthesis and Metabolism in Metastatic Prostate Cancer Tumors. Cancer Res. 2012, 72, 6142-6152. [CrossRef] [PubMed]

14. Visakorpi, T.; Hyytinen, E.; Koivisto, P.; Tanner, M.; Keinanen, R.; Palmberg, C.; Palotie, A.; Tammela, T.; Isola, J.; Kallioniemi, O.P. In Vivo Amplification of the Androgen Receptor Gene and Progression of Human Prostate Cancer. Nat. Genet. 1995, 9, 401-406. [CrossRef] [PubMed]

15. Newmark, J.R.; Hardy, D.O.; Tonb, D.C.; Carter, B.S.; Epstein, J.I.; Isaacs, W.B.; Brown, T.R.; Barrack, E.R. Androgen Receptor Gene Mutations in Human Prostate Cancer. Proc. Natl. Acad. Sci. USA 1992, 89, 6319-6323. [CrossRef]

16. Taplin, M.E.; Bubley, G.J.; Shuster, T.D.; Frantz, M.E.; Spooner, A.E.; Ogata, G.K.; Keer, H.N.; Balk, S.P. Mutation of the Androgen-Receptor Gene in Metastatic Androgen-Independent Prostate Cancer. N. Engl. J. Med. 1995, 332, 1393-1398. [CrossRef]

17. Chen, C.D.; Welsbie, D.S.; Tran, C.; Baek, S.H.; Chen, R.; Vessella, R.; Rosenfeld, M.G.; Sawyers, C.L. Molecular Determinants of Resistance to Antiandrogen Therapy. Nat. Med. 2004, 10, 33-39. [CrossRef]

18. Dehm, S.M.; Schmidt, L.J.; Heemers, H.V.; Vessella, R.L.; Tindall, D.J. Splicing of a Novel Androgen Receptor Exon Generates a Constitutively Active Androgen Receptor that Mediates Prostate Cancer Therapy Resistance. Cancer Res. 2008, 68, 5469-5477. [CrossRef] [PubMed]

19. Hu, R.; Dunn, T.A.; Wei, S.; Isharwal, S.; Veltri, R.W.; Humphreys, E.; Han, M.; Partin, A.W.; Vessella, R.L.; Isaacs, W.B.; et al. Ligand-Independent Androgen Receptor Variants Derived from Splicing of Cryptic Exons Signify Hormone-Refractory Prostate Cancer. Cancer Res. 2009, 69, 16-22. [CrossRef] 
20. Hu, R.; Lu, C.; Mostaghel, E.A.; Yegnasubramanian, S.; Gurel, M.; Tannahill, C.; Edwards, J.; Isaacs, W.B.; Nelson, P.S.; Bluemn, E.; et al. Distinct Transcriptional Programs Mediated by the Ligand-Dependent Full-Length Androgen Receptor and its Splice Variants in Castration-Resistant Prostate Cancer. Cancer Res. 2012, 72, 3457-3462. [CrossRef]

21. McConnell, J.D. Prostatic Growth: New Insights into Hormonal Regulation. Br. J. Urol. 1995, 76 (Suppl. S1), 5-10.

22. Zhang, A.; Zhang, J.; Plymate, S.; Mostaghel, E.A. Classical and Non-Classical Roles for Pre-Receptor Control of DHT Metabolism in Prostate Cancer Progression. Horm. Cancer 2016, 7, 104-113. [CrossRef]

23. Simental, J.A.; Sar, M.; Lane, M.V.; French, F.S.; Wilson, E.M. Transcriptional Activation and Nuclear Targeting Signals of the Human Androgen Receptor. J. Biol. Chem. 1991, 266, 510-518. [CrossRef]

24. Claessens, F.; Denayer, S.; Van Tilborgh, N.; Kerkhofs, S.; Helsen, C.; Haelens, A. Diverse Roles of Androgen Receptor (AR) Domains in AR-Mediated Signaling. Nucl. Recept. Signal. 2008, 6, e008. [CrossRef] [PubMed]

25. Feldman, B.J.; Feldman, D. The Development of Androgen-Independent Prostate Cancer. Nat. Rev. Cancer 2001, 1, 34-45. [PubMed]

26. Merkle, D.; Hoffmann, R. Roles of cAMP and cAMP-Dependent Protein Kinase in the Progression of Prostate Cancer: Cross-Talk with the Androgen Receptor. Cell Signal. 2011, 23, 507-515. [CrossRef]

27. Sadar, M.D. Androgen-Independent Induction of Prostate-Specific Antigen Gene Expression Via Cross-Talk between the Androgen Receptor and Protein Kinase A Signal Transduction Pathways. J. Biol. Chem. 1999, 274, 7777-7783. [CrossRef]

28. Laurenza, A.; Sutkowski, E.M.; Seamon, K.B. Forskolin: A Specific Stimulator of Adenylyl Cyclase Or a Diterpene with Multiple Sites of Action? Trends Pharmacol. Sci. 1989, 10, 442-447. [CrossRef]

29. Montminy, M. Transcriptional Regulation by Cyclic AMP. Annu. Rev. Biochem. 1997, 66, 807-822. [CrossRef]

30. Grossmann, M.E.; Huang, H.; Tindall, D.J. Androgen Receptor Signaling in Androgen-Refractory Prostate Cancer. J. Natl. Cancer Inst. 2001, 93, 1687-1697. [CrossRef]

31. Blok, L.J.; de Ruiter, P.E.; Brinkmann, A.O. Forskolin-Induced Dephosphorylation of the Androgen Receptor Impairs Ligand Binding. Biochemistry 1998, 37, 3850-3857. [CrossRef] [PubMed]

32. Sadar, M.D.; Hussain, M.; Bruchovsky, N. Prostate Cancer: Molecular Biology of Early Progression to Androgen Independence. Endocr. Relat. Cancer 1999, 6, 487-502. [CrossRef] [PubMed]

33. Meehan, K.L.; Sadar, M.D. Quantitative Profiling of LNCaP Prostate Cancer Cells using Isotope-Coded Affinity Tags and Mass Spectrometry. Proteomics 2004, 4, 1116-1134. [CrossRef] [PubMed]

34. Wang, G.; Jones, S.J.; Marra, M.A.; Sadar, M.D. Identification of Genes Targeted by the Androgen and PKA Signaling Pathways in Prostate Cancer Cells. Oncogene 2006, 25, 7311-7323. [CrossRef]

35. Cha, S.; Shin, D.H.; Seok, J.R.; Myung, J.K. Differential Proteome Expression Analysis of Androgen-Dependent and -Independent Pathways in LNCaP Prostate Cancer Cells. Exp. Cell Res. 2017, 359, 215-225. [CrossRef]

36. Yamada, Y.; Beltran, H. Clinical and Biological Features of Neuroendocrine Prostate Cancer. Curr. Oncol. Rep. 2021, 23, 15. [CrossRef]

37. Liu, J.; Lichtenberg, T.; Hoadley, K.A.; Poisson, L.M.; Lazar, A.J.; Cherniack, A.D.; Kovatich, A.J.; Benz, C.C.; Levine, D.A.; Lee, A.V.; et al. An Integrated TCGA Pan-Cancer Clinical Data Resource to Drive High-Quality Survival Outcome Analytics. Cell 2018, 173, 400-416. [CrossRef]

38. Uo, T.; Sprenger, C.C.; Plymate, S.R. Androgen Receptor Signaling and Metabolic and Cellular Plasticity during Progression to Castration Resistant Prostate Cancer. Front. Oncol. 2020, 10, 580617. [CrossRef]

39. Sharief, F.S.; Mohler, J.L.; Sharief, Y.; Li, S.S. Expression of Human Prostatic Acid Phosphatase and Prostate Specific Antigen Genes in Neoplastic and Benign Tissues. Biochem. Mol. Biol. Int. 1994, 33, 567-574.

40. Li, S.S.; Sharief, F.S. The Prostatic Acid Phosphatase (ACPP) Gene is Localized to Human Chromosome 3q21-q23. Genomics 1993, 17, 765-766. [CrossRef]

41. Li, S.S. Human Prostatic Acid Phosphatase and Prostate Specific Antigen: Protein Structure, Gene Organization, and Expression in Neoplastic and Benign Tissues. Kaohsiung J. Med. Sci. 1996, 12, 441-447.

42. Sun, C.; Song, C.; Ma, Z.; Xu, K.; Zhang, Y.; Jin, H.; Tong, S.; Ding, W.; Xia, G.; Ding, Q. Periostin Identified as a Potential Biomarker of Prostate Cancer by iTRAQ-Proteomics Analysis of Prostate Biopsy. Proteome Sci. 2011, 9, 22. [CrossRef]

43. Shipitsin, M.; Small, C.; Choudhury, S.; Giladi, E.; Friedlander, S.; Nardone, J.; Hussain, S.; Hurley, A.D.; Ernst, C.; Huang, Y.E.; et al. Identification of Proteomic Biomarkers Predicting Prostate Cancer Aggressiveness and Lethality Despite Biopsy-Sampling Error. Br. J. Cancer 2014, 111, 1201-1212. [CrossRef]

44. Vander Heiden, M.G.; Cantley, L.C.; Thompson, C.B. Understanding the Warburg Effect: The Metabolic Requirements of Cell Proliferation. Science 2009, 324, 1029-1033. [CrossRef] [PubMed]

45. Dennison, J.B.; Molina, J.R.; Mitra, S.; Gonzalez-Angulo, A.M.; Balko, J.M.; Kuba, M.G.; Sanders, M.E.; Pinto, J.A.; Gomez, H.L.; Arteaga, C.L.; et al. Lactate Dehydrogenase B: A Metabolic Marker of Response to Neoadjuvant Chemotherapy in Breast Cancer. Clin. Cancer Res. 2013, 19, 3703-3713. [CrossRef] [PubMed]

46. Moir, J.A.G.; Long, A.; Haugk, B.; French, J.J.; Charnley, R.M.; Manas, D.M.; Wedge, S.R.; Mann, J.; Robinson, S.M.; White, S.A. Therapeutic Strategies Toward Lactate Dehydrogenase within the Tumor Microenvironment of Pancreatic Cancer. Pancreas 2020, 49, 1364-1371. [CrossRef] [PubMed] 
47. Rosso, M.; Lapyckyj, L.; Besso, M.J.; Monge, M.; Reventos, J.; Canals, F.; Quevedo Cuenca, J.O.; Matos, M.L.; Vazquez-Levin, M.H. Characterization of the Molecular Changes Associated with the Overexpression of a Novel Epithelial Cadherin Splice Variant mRNA in a Breast Cancer Model using Proteomics and Bioinformatics Approaches: Identification of Changes in Cell Metabolism and an Increased Expression of Lactate Dehydrogenase B. Cancer Metab. 2019, 7, 5. [PubMed]

48. Pang, J.; Liu, W.P.; Liu, X.P.; Li, L.Y.; Fang, Y.Q.; Sun, Q.P.; Liu, S.J.; Li, M.T.; Su, Z.L.; Gao, X. Profiling Protein Markers Associated with Lymph Node Metastasis in Prostate Cancer by DIGE-Based Proteomics Analysis. J. Proteome Res. 2010, 9, 216-226. [CrossRef] [PubMed]

49. Burgess, E.F.; Ham, A.J.; Tabb, D.L.; Billheimer, D.; Roth, B.J.; Chang, S.S.; Cookson, M.S.; Hinton, T.J.; Cheek, K.L.; Hill, S.; et al. Prostate Cancer Serum Biomarker Discovery through Proteomic Analysis of Alpha-2 Macroglobulin Protein Complexes. Proteomics Clin. Appl. 2008, 2, 1223. [CrossRef]

50. Mitchell, G.A.; Kassovska-Bratinova, S.; Boukaftane, Y.; Robert, M.F.; Wang, S.P.; Ashmarina, L.; Lambert, M.; Lapierre, P.; Potier, E. Medical Aspects of Ketone Body Metabolism. Clin. Investig. Med. 1995, 18, 193-216.

51. Garcia-Caballero, M.; Zecchin, A.; Souffreau, J.; Truong, A.K.; Teuwen, L.A.; Vermaelen, W.; Martin-Perez, R.; de Zeeuw, P.; Bouche, A.; Vinckier, S.; et al. Role and Therapeutic Potential of Dietary Ketone Bodies in Lymph Vessel Growth. Nat. Metab. 2019, 1, 666-675. [CrossRef] [PubMed]

52. Saraon, P.; Cretu, D.; Musrap, N.; Karagiannis, G.S.; Batruch, I.; Drabovich, A.P.; van der Kwast, T.; Mizokami, A.; Morrissey, C.; Jarvi, K.; et al. Quantitative Proteomics Reveals that Enzymes of the Ketogenic Pathway are Associated with Prostate Cancer Progression. Mol. Cell. Proteomics 2013, 12, 1589-1601.

53. Costello, L.C.; Franklin, R.B. Citrate Metabolism of Normal and Malignant Prostate Epithelial Cells. Urology 1997, 50, 3-12. [CrossRef]

54. Epstein, J.I.; Allsbrook, W.C., Jr.; Amin, M.B.; Egevad, L.L.; ISUP Grading Committee. The 2005 International Society of Urological Pathology (ISUP) Consensus Conference on Gleason Grading of Prostatic Carcinoma. Am. J. Surg. Pathol. 2005, 29, 1228-1242. [CrossRef]

55. Humphrey, P.A. Gleason Grading and Prognostic Factors in Carcinoma of the Prostate. Mod. Pathol. 2004, 17, 292-306. [CrossRef]

56. Epstein, J.I.; Zelefsky, M.J.; Sjoberg, D.D.; Nelson, J.B.; Egevad, L.; Magi-Galluzzi, C.; Vickers, A.J.; Parwani, A.V.; Reuter, V.E.; Fine, S.W.; et al. A Contemporary Prostate Cancer Grading System: A Validated Alternative to the Gleason Score. Eur. Urol. 2016, 69, 428-435. [CrossRef]

57. Magee, J.A.; Araki, T.; Patil, S.; Ehrig, T.; True, L.; Humphrey, P.A.; Catalona, W.J.; Watson, M.A.; Milbrandt, J. Expression Profiling Reveals Hepsin Overexpression in Prostate Cancer. Cancer Res. 2001, 61, 5692-5696.

58. Welsh, J.B.; Sapinoso, L.M.; Su, A.I.; Kern, S.G.; Wang-Rodriguez, J.; Moskaluk, C.A.; Frierson, H.F., Jr.; Hampton, G.M. Analysis of Gene Expression Identifies Candidate Markers and Pharmacological Targets in Prostate Cancer. Cancer Res. 2001, 61, 5974-5978.

59. Singh, D.; Febbo, P.G.; Ross, K.; Jackson, D.G.; Manola, J.; Ladd, C.; Tamayo, P.; Renshaw, A.A.; D'Amico, A.V.; Richie, J.P.; et al. Gene Expression Correlates of Clinical Prostate Cancer Behavior. Cancer Cell 2002, 1, 203-209. [CrossRef]

60. Lapointe, J.; Li, C.; Higgins, J.P.; van de Rijn, M.; Bair, E.; Montgomery, K.; Ferrari, M.; Egevad, L.; Rayford, W.; Bergerheim, U.; et al. Gene Expression Profiling Identifies Clinically Relevant Subtypes of Prostate Cancer. Proc. Natl. Acad. Sci. USA 2004, 101, 811-816. [CrossRef] [PubMed]

61. Grasso, C.S.; Wu, Y.M.; Robinson, D.R.; Cao, X.; Dhanasekaran, S.M.; Khan, A.P.; Quist, M.J.; Jing, X.; Lonigro, R.J.; Brenner, J.C.; et al. The Mutational Landscape of Lethal Castration-Resistant Prostate Cancer. Nature 2012, 487, $239-243$. [CrossRef]

62. Tomlins, S.A.; Mehra, R.; Rhodes, D.R.; Cao, X.; Wang, L.; Dhanasekaran, S.M.; Kalyana-Sundaram, S.; Wei, J.T.; Rubin, M.A.; Pienta, K.J.; et al. Integrative Molecular Concept Modeling of Prostate Cancer Progression. Nat. Genet. 2007, 39, 41-51. [CrossRef]

63. Luo, J.; Duggan, D.J.; Chen, Y.; Sauvageot, J.; Ewing, C.M.; Bittner, M.L.; Trent, J.M.; Isaacs, W.B. Human Prostate Cancer and Benign Prostatic Hyperplasia: Molecular Dissection by Gene Expression Profiling. Cancer Res. 2001, 61, 4683-4688. [PubMed]

64. Vanaja, D.K.; Cheville, J.C.; Iturria, S.J.; Young, C.Y. Transcriptional Silencing of Zinc Finger Protein 185 Identified by Expression Profiling is Associated with Prostate Cancer Progression. Cancer Res. 2003, 63, 3877-3882. [PubMed]

65. Arredouani, M.S.; Lu, B.; Bhasin, M.; Eljanne, M.; Yue, W.; Mosquera, J.M.; Bubley, G.J.; Li, V.; Rubin, M.A.; Libermann, T.A.; et al. Identification of the Transcription Factor Single-Minded Homologue 2 as a Potential Biomarker and Immunotherapy Target in Prostate Cancer. Clin. Cancer Res. 2009, 15, 5794-5802. [CrossRef]

66. Yu, Y.P.; Landsittel, D.; Jing, L.; Nelson, J.; Ren, B.; Liu, L.; McDonald, C.; Thomas, R.; Dhir, R.; Finkelstein, S.; et al. Gene Expression Alterations in Prostate Cancer Predicting Tumor Aggression and Preceding Development of Malignancy. J. Clin. Oncol. 2004, 22, 2790-2799. [CrossRef]

67. Sharp, A.; Coleman, I.; Yuan, W.; Sprenger, C.; Dolling, D.; Rodrigues, D.N.; Russo, J.W.; Figueiredo, I.; Bertan, C.; Seed, G.; et al. Androgen Receptor Splice Variant-7 Expression Emerges with Castration Resistance in Prostate Cancer. J. Clin. Investig. 2019, 129, 192-208. [CrossRef]

68. Mishra, D.; Banerjee, D. Lactate Dehydrogenases as Metabolic Links between Tumor and Stroma in the Tumor Microenvironment. Cancers 2019, 11, 750. [CrossRef]

69. Kiran, D.; Basaraba, R.J. Lactate Metabolism and Signaling in Tuberculosis and Cancer: A Comparative Review. Front. Cell. Infect. Microbiol. 2021, 11, 624607. [CrossRef] 
70. Leiblich, A.; Cross, S.S.; Catto, J.W.; Phillips, J.T.; Leung, H.Y.; Hamdy, F.C.; Rehman, I. Lactate Dehydrogenase-B is Silenced by Promoter Hypermethylation in Human Prostate Cancer. Oncogene 2006, 25, 2953-2960. [CrossRef]

71. Liu, J.; Chen, G.; Liu, Z.; Liu, S.; Cai, Z.; You, P.; Ke, Y.; Lai, L.; Huang, Y.; Gao, H.; et al. Aberrant FGFR Tyrosine Kinase Signaling Enhances the Warburg Effect by Reprogramming LDH Isoform Expression and Activity in Prostate Cancer. Cancer Res. 2018, 78, 4459-4470. [CrossRef]

72. Bok, R.; Lee, J.; Sriram, R.; Keshari, K.; Sukumar, S.; Daneshmandi, S.; Korenchan, D.E.; Flavell, R.R.; Vigneron, D.B.; Kurhanewicz, J.; et al. The Role of Lactate Metabolism in Prostate Cancer Progression and Metastases Revealed by Dual-Agent Hyperpolarized (13)C MRSI. Cancers 2019, 11, 257. [CrossRef]

73. McCleland, M.L.; Adler, A.S.; Deming, L.; Cosino, E.; Lee, L.; Blackwood, E.M.; Solon, M.; Tao, J.; Li, L.; Shames, D.; et al. Lactate Dehydrogenase B is Required for the Growth of KRAS-Dependent Lung Adenocarcinomas. Clin. Cancer Res. 2013, 19, 773-784. [CrossRef]

74. McCleland, M.L.; Adler, A.S.; Shang, Y.; Hunsaker, T.; Truong, T.; Peterson, D.; Torres, E.; Li, L.; Haley, B.; Stephan, J.P.; et al. An Integrated Genomic Screen Identifies LDHB as an Essential Gene for Triple-Negative Breast Cancer. Cancer Res. 2012, 72, 5812-5823. [CrossRef]

75. Brisson, L.; Banski, P.; Sboarina, M.; Dethier, C.; Danhier, P.; Fontenille, M.J.; Van Hee, V.F.; Vazeille, T.; Tardy, M.; Falces, J.; et al. Lactate Dehydrogenase B Controls Lysosome Activity and Autophagy in Cancer. Cancer Cell 2016, 30, 418-431. [CrossRef]

76. Wang, W.; Hedstrom, L. Kinetic Mechanism of Human Inosine 5'-Monophosphate Dehydrogenase Type II: Random Addition of Substrates and Ordered Release of Products. Biochemistry 1997, 36, 8479-8483. [CrossRef]

77. Kozhevnikova, E.N.; van der Knaap, J.A.; Pindyurin, A.V.; Ozgur, Z.; van Ijcken, W.F.; Moshkin, Y.M.; Verrijzer, C.P. Metabolic Enzyme IMPDH is also a Transcription Factor Regulated by Cellular State. Mol. Cell 2012, 47, 133-139. [CrossRef] [PubMed]

78. Zhou, L.; Xia, D.; Zhu, J.; Chen, Y.; Chen, G.; Mo, R.; Zeng, Y.; Dai, Q.; He, H.; Liang, Y.; et al. Enhanced Expression of IMPDH2 Promotes Metastasis and Advanced Tumor Progression in Patients with Prostate Cancer. Clin. Transl. Oncol. 2014, 16, 906-913. [CrossRef] [PubMed]

79. Han, Z.D.; Zhang, Y.Q.; He, H.C.; Dai, Q.S.; Qin, G.Q.; Chen, J.H.; Cai, C.; Fu, X.; Bi, X.C.; Zhu, J.G.; et al. Identification of Novel Serological Tumor Markers for Human Prostate Cancer using Integrative Transcriptome and Proteome Analysis. Med. Oncol. 2012, 29, 2877-2888. [CrossRef]

80. Barfeld, S.J.; Fazli, L.; Persson, M.; Marjavaara, L.; Urbanucci, A.; Kaukoniemi, K.M.; Rennie, P.S.; Ceder, Y.; Chabes, A.; Visakorpi, T.; et al. Myc-Dependent Purine Biosynthesis Affects Nucleolar Stress and Therapy Response in Prostate Cancer. Oncotarget 2015, 6, 12587-12602. [CrossRef]

81. Ciarlo, M.; Benelli, R.; Barbieri, O.; Minghelli, S.; Barboro, P.; Balbi, C.; Ferrari, N. Regulation of Neuroendocrine Differentiation by AKT/hnRNPK/AR/beta-Catenin Signaling in Prostate Cancer Cells. Int. J. Cancer 2012, 131, 582-590. [CrossRef]

82. Jia, Z.; Zhu, J.; Zhuo, Y.; Li, R.; Qu, H.; Wang, S.; Wang, M.; Lu, J.; Chater, J.M.; Ma, R.; et al. Offsetting Expression Profiles of Prognostic Markers in Prostate Tumor Vs. its Microenvironment. Front. Oncol. 2019, 9, 539. [CrossRef]

83. Zhang, D.; Hu, Q.; Liu, X.; Ji, Y.; Chao, H.P.; Liu, Y.; Tracz, A.; Kirk, J.; Buonamici, S.; Zhu, P.; et al. Intron Retention is a Hallmark and Spliceosome Represents a Therapeutic Vulnerability in Aggressive Prostate Cancer. Nat. Commun. 2020, 11, 2089. [CrossRef]

84. Khan, A.P.; Poisson, L.M.; Bhat, V.B.; Fermin, D.; Zhao, R.; Kalyana-Sundaram, S.; Michailidis, G.; Nesvizhskii, A.I.; Omenn, G.S.; Chinnaiyan, A.M.; et al. Quantitative Proteomic Profiling of Prostate Cancer Reveals a Role for miR-128 in Prostate Cancer. Mol. Cell. Proteomics 2010, 9, 298-312.

85. Flores, O.; Santra, S.; Kaittanis, C.; Bassiouni, R.; Khaled, A.S.; Khaled, A.R.; Grimm, J.; Perez, J.M. PSMA-Targeted Theranostic Nanocarrier for Prostate Cancer. Theranostics 2017, 7, 2477-2494. [CrossRef]

86. Carr, A.C.; Khaled, A.S.; Bassiouni, R.; Flores, O.; Nierenberg, D.; Bhatti, H.; Vishnubhotla, P.; Manuel, J.P.; Santra, S.; Khaled, A.R. Targeting Chaperonin Containing TCP1 (CCT) as a Molecular Therapeutic for Small Cell Lung Cancer. Oncotarget 2017, 8, 110273-110288. [CrossRef]

87. Labrecque, M.P.; Coleman, I.M.; Brown, L.G.; True, L.D.; Kollath, L.; Lakely, B.; Nguyen, H.M.; Yang, Y.C.; da Costa, R.M.G.; Kaipainen, A.; et al. Molecular Profiling Stratifies Diverse Phenotypes of Treatment-Refractory Metastatic Castration-Resistant Prostate Cancer. J. Clin. Investig. 2019, 129, 4492-4505. [CrossRef]

88. Labrecque, M.P.; Alumkal, J.J.; Coleman, I.M.; Nelson, P.S.; Morrissey, C. The Heterogeneity of Prostate Cancers Lacking AR Activity Will Require Diverse Treatment Approaches. Endocr. Relat. Cancer 2021, 28, T51-T66. [CrossRef] 